\title{
PENGARUH MARKETING MIX TERHADAP LOYALITAS PELANGGAN
}

\author{
Evi Husniati Sya'idah \\ Tontowi Jauhari \\ Fakultas Ilmu Kesehatan, Universitas Kadiri \\ evihusniati@unik-kediri.ac.id \\ Tontowi@unik-kediri.ac.id
}

\begin{abstract}
This study is aimed at knowing the influence of marketing mix towards customers' loyalty. Accordingly, method used in this study is descriptive quantitative. The population of this study is the customers of bubur ayam mezem in Kediri. Moreover, the sample used in this study is 100 customers. In accordance with statistical analysis, the result of this study is as follow: (1) marketing mix that consists of product, price, and place has simultaneously a positive influence towards customers' loyalty; (2) promotion has a negative influence towards customers' loyalty. Thus, it can be inferred that if product, price, and place are increasing, the customers' loyalty will be increasing as well. On the contrary, if promotion is increasing, the customers' loyalty will be decreasing.
\end{abstract}

Keywords: marketing mix, customers' loyalty

\begin{abstract}
Abstrak
Tujuan yang hendak dicapai melalui penelitian ini adalah untuk mengetahui pengaruh marketing mix terhadap loyalitas pelanggan. Penelitian ini menggunakan metode deskriptif kuantitatif. Populasi yang digunakan dalam penelitian ini adalah pelanggan bubur ayam mezem di Kediri dengan sampel sebanyak 100 orang pelanggan. Dari penelitian ini diperoleh hasil: (1) produk, harga dan tempat secara bersama-sama memiliki pengaruh positif; (2) promosi memiliki pengaruh negatif terhadap loyalitas pelanggan. Maka dapat ditarik kesimpulan bahwa jika produk, harga dan tempat dinaikkan maka loyalitas pelanggan juga ikut naik, tetapi jika promosi naik maka loyalitas pelanggan turun.
\end{abstract}

Kata kunci: marketing mix, loyalitas pelanggan

\section{PENDAHULUAN}

Loyalitas pelanggan yang dipengaruhi oleh marketing mix diharapkan mampu memberikan dampak positif terhadap kelangsungan sebuah usaha. Salah satu bentuk strategi pemasaran yang mampu mendukung dalam memasarkan produk untuk menciptakan kepuasan pelanggan adalah dengan menerapkan bauran pemasaran (marketing mix) yang meliputi product, price, place/Distribution dan Promotion (Abdul 
manap, 2016). Oleh karena itu diharapkan loyalitas pelanggan dalam membeli suatu dapat meningkat dengan adanya variabel-variabel yang didalam marketing mix.

Hasil penelitian yang dilakukan Sawitri (2016) menunjukkan adanya pengaruh yang signifikan dan positif antara marketing mix (produk, promosi, tempat, orang, proses) terhadap kepuasan konsumen. Selain itu, Nurullaili dan Wijayanto Andi (2013) menyatakan bahwa faktor yang paling berpengaruh terhadap loyalitas pelanggan adalah harga. Hasil penelitian Octaviani dkk (2014) menyatakan bahwa variable produk merupakan varibel yang paling dominan yang berpengaruh tehadap pengambilan keputusan pembelian.

Oleh karena itu,penelitian bertujuan untuk mengetahui pengaruh marketing mix terhadap loyalitas pelanggan Bubur Ayam Mezem di Kota Kediri

\section{TINJAUAN PUSTAKA}

\section{Pengertian Pemasaran}

Menurut Alma (2012:11) Pemasaran adalah kegiatan memasarkan barang, tidak berarti hanya menawarkan barang atau menjual dengan segala macam cara yang menyangkut barang, menyimpan dan mensortir.

Selain itu, Kotler dan amstrong (2008) mengatakan bahwa pemasaran merupakan suatu cara pengusaha untuk membangun hubungan baik dengan pelanggan dengan tujuan untuk menciptakan hubungan yang baik dan mendapatkan kepercayaan dari pelanggan.

Dari beberapa definisi diatas, dapat ditarik kesimpulan bahwa seluruh kegiatan pemasaran ditunjukan untuk memenuhi dan memuaskan kebutuhan manusia serta membina hubungan baik dengan pelanggan melalui proses pertukaran serta kegiatan pemasaran tersebut merupakan kegiatan yang saling berhubungan sebagai suatu sistem.

Ini berarti bahwa seluruh kegiatan pemasaran harus berorientasi pada pasar atau konsumen, dan dalam menentukan konsumen ini dibutuhkan beberapa pertimbangan yang menyangkut tentang produk, tempat, harga dan promosi.

\section{Pengertian Bauran Pemasaran (marketing mix)}

Menurut Lupiyoadi (2013), bauran pemasaran adalah sebuah piranti bagi pemasar yang terdiri atas berbagai unsur dalam suatu program pemasaran yang perlu ditinjau ulang 
supaya pelaksanaan strategi pemasaran dan penentuan posisi yang telah ditetapkan dapat berjalan sesuai dengan yang diharapakan.

Adapun unsur-unsur bauran pemasaran tersebut adalah sebagai berikut:

\section{a. Product (Produk)}

Menurut Kotler dan Armstrong (2012:18) produk adalah barang atau jasa dapat diperjual belikan dalam pasar untuk dimanfaatkan sehingga dapat memenuhi kebutuhan dan keinginan penjual dan pembeli.

b. Price (Harga)

Menurut Kotler dan Amstrong (2010:314) Harga adalah sejumlah nilai tukar berupa uang yang dilekatkan pada barang atau jasa atas manfaat karena memiliki dana atau menggunakannya.

c. Tempat/Distribusi (Place/Distribution)

Perantara disini sangat penting, karena dalam segala hal mereka berhubungan langsung dengan konsumen. Pemilihan lokasi juga tidak kalah penting, pemilihan lokasi merupakan nilai investasi yang paling mahal, sebab lokasi bisa dikatakan menentukan ramai atau tidaknya pengunjung, terutama bisnis kuliner. Lokasi usaha yang berada di pinggir jalan atau ditempat yang strategis cukup menyedot pengunjung untuk sekedar mampir dan mencicipi hidangan.

d. Promosi

Kegiatan promosi pada pemasaran modern seperti sekarang ini perlu mendapatkan perhatian khusus, dimana produsen sangat mengandalkan, sangat memberi harapan tinggi akan meningkatnya penjualan dengan promosi sebagai ujung tombaknya.

\section{Loyalitas Pelanggan}

Menurut Lodh (2011) pelanggan yang loyal adalah pelanggan yang memiliki karakteristik tertentu sebagai berikut: (1) melakukan pembelian secara berulang-ulang pada badan usaha yang sama; (2) membeli produk dan atau jasa yang ditawarkan oleh badan usaha yang sama; (3) memberitahukan pada orang lain tentang kepuasan-kepuasan yang diperoleh dari badan usaha dan menunjukan kekebalan terhadap tawaran dari pesaing untuk produk atau jasa yang sama. 


\section{Kerangka Konseptual}

Kerangka koseptual ditunjukkan pada gambar 2.1
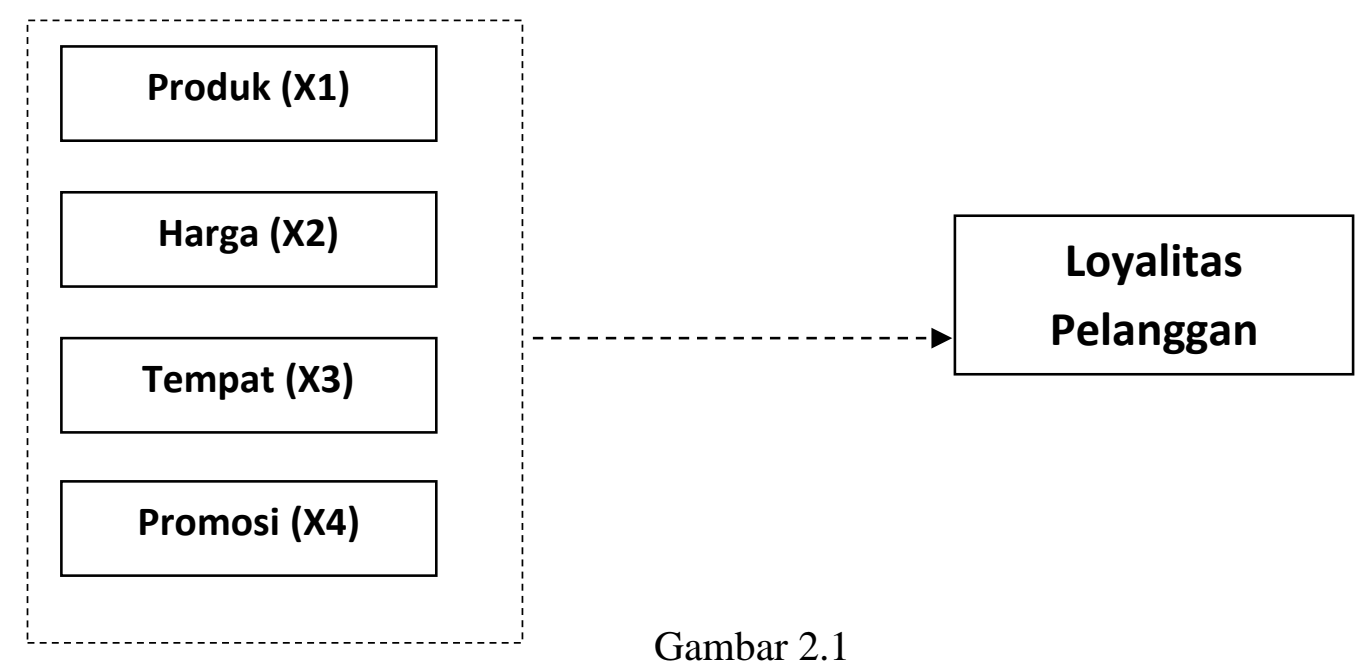

Gambar 2.1

Kerangka Konsep Penelitian

\section{Hipotesis}

$\mathrm{H}_{\mathrm{a}}$ : terdapat pengaruh antara produk, harga, tempat dan promosi terhadap loyalitas pelanggan pada bubur ayam mezem di Kediri.

\section{METODE PENELITIAN}

Penelitian ini merupakan penelitian deskriptif dengan pendekatan kuantitatif. Pengumpulan data dilakukan dengan cara observasi, interview, dan kuesioner. Populasi dalam penelitian ini adalah seluruh pelanggan bubur ayam mezem dengan sampel 100 responden. Variabel yang digunakan sebagai variabel bebas $(\mathrm{X})$ adalah bauran pemasaran (marketing mix) yaitu: Produk (X1), harga (X2), tempat (X3), dan promosi (X4). Untuk variabel terikat $(\mathrm{Y})$ adalah loyalitas pelanggan.

\section{Pengukuran Variabel}

Untuk mendapatkan data kuantitatif, maka digunakan skala likert. Hal tersebut diperoleh dari daftar pertanyaan yang dikelompokan kedalam lima tingkatan nilai sebagai berikut (sugiono,2010):

1. Untuk jawaban STS diberi nilai 1

2. Untuk jawaban TS diberi nilai 2

3. Untuk jawaban RR diberi nilai 3 
4. Untuk jawaban $\mathrm{S}$ diberi nilai 4

5. Untuk jawaban SS diberi nilai 5

\section{Pengujian Instrumen}

Sebelum didistribusikan kepada responden, instrument penelitian, kuesioner, terlebih dahulu diuji dengan menggunakan content validity (validitas isi) dengan hasil valid.

\section{Analisis Data}

Dalam penelitian ini menggunakan analisis regresi linear berganda sebagai cara untuk menganalisa data.

\section{HASIL DAN PEMBAHASAN}

\section{Regresi Linear Berganda}

Dalam penelitian ini menggunakan analisis regresi linear berganda untuk mengetahui besar pengaruh setiap variabel bebas terhadap variabel terikat.

Berdasarkan penghitungan regresi linear berganda antara produk $\left(\mathrm{X}_{1}\right)$, harga $\left(\mathrm{X}_{2}\right)$, tempat $\left(\mathrm{X}_{3}\right)$, terhadap pelanggan (Y) diperoleh hasil yang ditunjukkan pada tabel 4.1

\section{Tabel 4.1 Hasil Uji Regresi Linear Berganda}

Coefficients $^{\mathbf{a}}$
\begin{tabular}{|ll|r|r|r|}
\hline \multirow{2}{*}{ Model } & \multicolumn{2}{|c|}{$\begin{array}{c}\text { Standardized } \\
\text { Unstandardized Coefficients }\end{array}$} & \multicolumn{2}{c|}{ Coeficients } \\
\cline { 3 - 5 } & B & Std. Error & \multicolumn{2}{c|}{ Beta } \\
\hline 1 & (Constant) & -.534 & 1.097 & .200 \\
& Produk & .310 & .150 & .411 \\
& Harga & .435 & .140 & .298 \\
& Tempat & .492 & .165 & -.155 \\
& Promosi & -.273 & .202 & \\
\end{tabular}

a. Dependent Variable: Loyalitas

Berdasarkan tabel tersebut maka didapat persamaan regresi sebagai berikut:

$$
Y=-0,534+0.310 X_{1}+0.435 X_{2}+0,492 X_{3}-0.273 X_{4}+e
$$

1. Konstanta (a) -0.534

Konstanta (a) sebesar -0.534 memberikan pengertian bahwa jika Produk, Harga, tempat, dan promosi dianggap sama dengan Nol, maka loyalitas pelanggan memiliki nilai negative sebesar -0.534 . 
2. Koefisien $X_{1}=0.310$

Jika variable produk mengalami kenaikan, sementara harga, tempat, dan promosi tetap maka loyalitas pelanggan akan meningkat 0,310 atau produk mempengaruhi loyalitas sebesar $31 \%$.

3. Koefisien $X_{2}=0.435$

Jika variable harga mengalami kenaikan, sementara produk, tempat, dan promosi diasumsikan tetap maka loyalitas pelanggan akan meningkat sebesar 0,435 atau harga dapat mempengaruhi loyalitas pelanggan sebesar 43,5\%.

4. Koefisien $X_{3}=0.492$

Jika variable tempat mengalami kenaikan, sementara produk, harga, dan promosi diasumsikan tetap maka loyalitas pelanggan akan meningkat sebesar 0,492 atau tempat dapat mempengaruhi loyalitas pelanggan sebesar 49,2\%.

5. Koefisien $X_{4}=-0.273$

Jika variable promosi mengalami kenaikan, sementara produk, harga, dan tempat diasumsikan tetap maka loyalitas pelanggan akan menurun sebesar 0,273 atau promosi dapat mempengaruhi loyalitas pelanggan sebesar $\quad 27,3 \%$.

\section{Uji Hipotesis}

Uji hipotesis menggunakan Uji Simultan (Uji F) dengan bantuan program SPSS, yang hasilnya ditunjukkan dalam tabel 4.2

Tabel 4.2

Hasil Uji Anova

1. ANOVA $^{\mathbf{a}}$

\begin{tabular}{|l|l|l|l|l|l|}
\hline Model & $\begin{array}{l}\text { Sum of } \\
\text { Squares }\end{array}$ & Df & $\begin{array}{l}\text { Mean } \\
\text { Square }\end{array}$ & F & Sig. \\
\hline Regression & 20.250 & 4 & 5.062 & 9.506 & $.000^{\mathrm{b}}$ \\
Residual & 50.590 & 95 & .533 & & \\
Total & 70.840 & 99 & & & \\
\hline
\end{tabular}

a. Dependent Variable: Loyalitas

b. Predictors: (Constant), promosi, produk, tempat, harga 
Dari tabel 4.2 hasil uji Anova maka di dapat $F_{\text {hitung }}$ sebesar 9,506 dengan tingkat signifikansi 0,000, karena nilai signifikansinya $<0,05$ maka $\mathrm{H}_{\mathrm{a}}$ diterima, yaitu produk, harga, tempat, dan promosi secara bersama-sama berpengaruh terhadap loyalitas pelanggan.

\section{Pembahasan}

Berdasarkan hasil dari $\mathrm{F}$ hitung sebesar 9,506 dengan tingkat signifikansi 0,000, karena nilai signifikansinya $<0,05$ maka $\mathrm{H}_{\mathrm{a}}$ diterima. Produk, Promosi, Harga, dan Tempat secara bersama-sama berpengaruh terhadap Loyalitas Pelanggan.

Produk dapat mempengaruhi loyalitas pelanggan dimana kemampuan produk untuk memuaskan kebutuhan atau keinginan konsumen (Cannon, dkk,2008).

Harga juga menjadi faktor yang mempengaruhi keputusan (Ruhamak, 2017) serta terjadinya pelanggan yang loyal terhadap toko karena harga merupakan sejumlah uang yang menghasilkan pendapatan (Widiyono dan Pakkanna,2013) bagi toko dan memberikan keuntungan bagi pelanggan.

Tempat juga menjadi faktor penentu loyalitas pelanggan karena tempat dapat lebih mudah menjangkau pelanggan dalam mendistribusikan barang kebutuhan mereka, karena distribusi merupakan kegiatan pemasaran yang berusaha memperlancar dan mempermudah penyampaian barang dan jasa dari produsen kepada konsumen, sehingga penggunaannya sesuai dengan yang diperlukan, Tjiptono (2012).

Berdasarkan pada data analisis regresi linier berganda tersebut menunjukkan bahwa promosi mempunyai pengaruh negative terhadap loyalitas pelanggan. Dalam hal ini dapat disimpulkan bahwa promosi tidak hanya memberikan dampak positif terhadap loyalitas pelanggan tapi juga bisa memberikan dampak negatif terhadap loyalitas pelanggan. Hal tersebut senada dengan Adeel (2014) yang menyatakan bahwa promosi tidak bisa serta merta mampu membangun loyalitas pelanggan terhadap produk. Terlebih lagi, menurut Kokemuller (2017) promosi penjualan secara terus menurus membuat pembeli lebih fokus terhadap harga murah.

\section{KESIMPULAN}

Berdasarkan analisis data dan pembahasan dapat ditarik kesimpulan bahwa produk, harga dan tempat berpengaruh positif terhadap loyalitas pelanggan. Sedangkan promosi berpengaruh negatif terhadap loyalitas pelanggan. 


\section{DAFTAR PUSTAKA}

Adeel, Muhammad. 2014. What are the disadvantages of sales promotion . sumber: https:// www.bayt.com/en/specialties/q/140830/what-are-the-disadnatages-ofsales-promotion/ diakses tanggal 10 Desember 2017.

Kokomuler,Neil. 2017. Advantages \& Disadvantages of Sales Promotion. Sumber: https://bizfluent.com/list-6673344-advantages-disadvantages-salespromotion.html. diakses tanggal 10 Desember 2017

Kotler, P dan G. Amstrong. 2008. Manajemen Pemasaran. PT. Indeks. Jakarta.

Kotler, P dan K. L. Keller. 2009. Manajemen Pemasaran. Edisi 12, Jilid 1. PT. Indeks. Jakarta.

Lodh. 2011. Manajemen Pemasaran Jasa. Salemba Empat. Jakarta

Lupiyoadi, Rambat. (2013). Manajemen Pemasaran Jasa : Berbasis Kompetensi, Edisi 3. Jakarta : Salemba Empat.

Manap,Abdul.2016. Revolusi Manajemen Pemasaran. Mitra Wacana Media. Jakarta

Nurullaili dan Wijayanto Andi (2013). Analisis Faktor-faktor yang mempengaruhi loyalitas konsumen Tupperware. Jurnal administrasi Bisnis, Volume 2, Nomor 1

Oktaviani,dkk.(2014).Pengaruh Bauran Pemasaran dan Perilaku Konsumen terhadap Keputusan Pembelian Jus Buah Segar Bandar Lampung. JIIA Vol.2, No.2

Ruhamak, M. D. (2017). Pengaruh marketing Mix dan Sikap Konsumen terhadap Keputusan Mengikuti kursus di LPK Progress Pare. Akuntabilitas, 9(2), 1-18. https://doi.org/https://doi.org/10.30957/akuntabilitas.v9i2.208

Ruhamak, D. (2017). pengaruh marketing mix dan sikap konsumen terhadap keputusan mengikuti kursus di lpk progress pare oleh. akuntabilitas: jurnal ilmiah ilmu-ilmu ekonomi, 9(2), 2.

Sawitri Dyah,dkk.(2016). Pengaruh Marketing mix terhadap loyalitas konsumen dengan variable intervening kepuasan pada Rumah Sakit Jiwa Dr. Radjiman Wediodiningrat. Jurnal Manajemen Bisnis Indonesia vol.4,no.1

Sugiyono. 2010. Metode Penelitian Kuantitaif, Kualitatif dan kombinasi (Mixed Methods). Alfabeta. Bandung.

Tjiptono,dkk. 2012. Pemasaran Strategik. ANDI. Jogyakarta

Waskita,indra alif.2016. Pengaruh Citra, Merk, Harga dan Promosi terhadap Loyalitas Konsumen.Jurnal Ilmu \& Riset Manajemen. ISSN:2461-0593 